\title{
Identifying Affirmative Beliefs about English Language Learning: Self-Perceptions of Thai Learners with Different Language Proficiency
}

\author{
Tuntiga Wang ${ }^{1} \&$ Krich Rajprasit ${ }^{1}$ \\ ${ }^{1}$ Language Center, International College for Sustainability Studies, Srinakharinwirot University, Thailand \\ Correspondence: Tuntiga Wang, 114 Sukhumvit, Wattana, Bangkok, Thailand. Tel: 668-6712-1799. E-mail: \\ tuntiga@g.swu.ac.th
}

Received: January 4, 2015 Accepted: February 7, 2015 Online Published: March 25, 2015

doi:10.5539/elt.v8n4p1 URL: http://dx.doi.org/10.5539/elt.v8n4p1

\begin{abstract}
Theoretically, beliefs about English language learning have a psychological factor, such as predicting the rate of success or failure among learners in the classroom context. However, learners with different levels of language proficiency may perceive such beliefs in a different way, which may lead to the development of special needs, in terms of emphasizing their sustainable language development. The present study aims a) to investigate self-reported beliefs about English language learning among both low and high proficiency Thai students in university-level Foundation English courses, b) to identify the most prevalent affirmative beliefs among both student groups, and c) to identify the similarities and differences in their beliefs. The findings revealed that for low-proficiency students, vocabulary was an essential aspect of English language learning, while for high-proficiency students, regular practice was the key to their success. They also believed that anybody could speak English, when given the opportunity to practice speaking. The most prevalent affirmative beliefs among both sets of students were a) that anybody can speak English if given the opportunity and the time to practice, b) studying in a country where English is spoken as a native language will increase their language proficiency, and c) they want access to information resources in English. There were ten major differences between their beliefs (i.e. to learn English well, one must know at least one other foreign language, and be good at mathematics and sciences). Such findings would be a valuable resource to assist in the redesigning of English language courses, especially general English at the tertiary level, for learners with different levels of language proficiency.
\end{abstract}

Keywords: beliefs about language learning, English language proficiency, Thai EFL learners

\section{Introduction}

The need for international communication is constantly on the increase, and people need a common language in order to effectively communicate with one another in the academic, professional, and social context. Many languages (i.e. English, French, Chinese, and Japanese) are used for cross-border communication between people from various countries in the globalized era. Of all of these languages, it is clear that English is the most commonly used language for such communication (Kitao, 1996; Pollap, 2010).

In an academic setting, the language is the primary foreign language that students are required to learn in most non-English-speaking nations (i.e. Thailand, China, Japan, and many others). However, the English language proficiency levels of these students are unsatisfactory, particularly Thai students. Despite studying English as their first foreign language from the elementary level, and as a compulsory subject in the regular Thai school system, their language proficiency level has been reported as lower than that of their counterparts in other South-East Asian countries, including Malaysia, the Philippines, and Singapore (Test and score data summary for TOEFL iBT $^{\circledR}$ test, 2013; Mitchell, 2013; Wiriyachitra, 2002).

Thus, various studies were conducted in order to identify the causes of this problem at all levels of the educational system, including the tertiary level, and to enhance the learning abilities of the students, such as an investigation into English learning and teaching techniques, English learning strategies, and addressing schemata in English learning. One of the research areas that tend to help scholars identify these causes are beliefs about language learning. Many researchers have established the direct effect of such beliefs on a student's performance in classroom context, and such beliefs are also correlated with motivation, autonomy, learning strategy use, experience, and anxiety (Abdolahzadeh \& Nia, 2014; Horwitz, 1999; Mohibi \& Khodadady, 2011; Peacock, 2001; Trinder, 2013). In other words, the rate of success or failure when learning a foreign language is basically 
determined by individual beliefs. Even though studies on the beliefs of learners regarding English language learning, and their relationship with a number of variables have been conducted, the differentiation of such beliefs among students with different levels of language proficiency has yet to be found, especially in the Thai tertiary education system. Such a study would provide tremendous advantages for all stakeholders, as it would identify specific, insightful evidence for the improvement of language courses. Therefore, this study aims to investigate self-reported beliefs regarding English language learning among low and high proficiency students, to identify the most prevalent affirmative or positive beliefs among both low and high proficiency students, and identify the similarities and differences between the beliefs of both sets of students.

\section{Literature Review}

\subsection{English as a Foreign Language Instruction in Thailand}

English is widely regarded as the language for international communication in the institutional and non-institutional contexts, and is taught as a foreign language for the purpose of achieving communicative goals. The Thai government has taken a more active role in enhancing the development of English language proficiency. The government also announced that Thai students are required to learn English from Grade 1 onwards (Khamkhien, 2010). As a result of this announcement, students will study English for ten years before studying it at the tertiary level, where English is a compulsory subject for the first two years.

Moreover, becoming part of the ASEAN Economic Community (AEC) in 2015 has emphasized a major role of English as a working language in the region for Thai educational system. Therefore, well-designed language courses are required to prepare the future workforce to be at least competent communicators in English, or ideally, develop an even higher level of language proficiency. According to the test data regarding performance levels on the Test of English as a Foreign Language (TOEFL) in 2013, the English proficiency of Thai students is lower than that of other ASEAN countries. Thailand was ranked eighth out of ten countries, while Singapore, Malaysia, and the Philippines achieved the highest English proficiency levels (Test and score data summary for TOEFL iBT ${ }^{\circledR}$ test, 2013).

Some of the factors leading to unsuccessful English proficiency development, and failure in terms of teaching include factors such as the overemphasis placed on writing lessons, and insufficient use of or exposure to English used in real-life situations (Noom-ura, 2013). In addition, educators stated that many Thai students learned English by memorizing vocabulary and grammar rules. English language teachers in Thailand also paid too much attention to vocabulary and grammar instructions (Adam, 2011; Nguyen, 2005). Most of these students learned foreign languages by memorizing vocabulary and grammar rules for the sole purpose of passing exams (Adam, 2011; Nguyen, 2005). Thus, their learning style can be compared to the subjects of Peacock's (2001) study; the population of trainee ESL teachers who also reported that language learning is primarily concerned with vocabulary, grammar acquisition and mastery.

From the perspective of the students, the factors leading to their failure to learn English include a lack of sufficient practice, a lack of exposure to English outside the classroom, a poor knowledge of English, and a lack of skills (Kaewmala, 2012; Noom-ura, 2013). Thai students may have the desire to improve their communicative skills; however, one of the most significant problems faced by Thai students is a lack of opportunity to practice these skills in their daily lives (Adam, 2011; Biyaem, 1997).

Therefore, the enhancement of communicative skills should be based on real-life situations, and the speaking practice and activities provided for the students should prepare them for everyday, real-life communication with foreigners (Kayi, 2006). Apparently, in the globalized era, a good knowledge of English also keeps the students up to date with modern information resources, such as the internet (Khunsamrong, 2010; Somdee \& Suppasetseree, 2013).

\subsection{Self-Perception in Language Learning}

The self-perceptions of students regarding language learning is another key factor in successful language learning, which is concerned with both personal judgments, and based on the performance levels of the students in course activities. According to the findings of theorists specializing in self-perception (Bandura, 1977; Shuck, 1997, Weiner, 1976), people have the potential to achieve their goals, and their positive or negative thoughts can be seen to lead to either success or failure. A positive self-perception can lead to positive results, such as success in language learning, as well as influencing the decision of the students in terms of engaging in class activities. Students obviously perform voluntarily and willingly in activities that they consider themselves capable of; on the other hand, they tend to avoid participating in those they believe to be beyond their ability. The theorists in this field revealed that the self-belief of students plays an important role in their actions, motivation, and 
achievement (Hsieh \& Kang, 2010). Ariogul, Unal, and Onursal (2009) confirm that high-proficiency students tend to be more motivated and confident about using English language than low-proficiency students.

There are sample studies in the field of investigating the beliefs of students regarding language learning, and using the support of self-perception theory to collect the data. Jernigan (2011) investigated Portuguese as Foreign Language students regarding their goals in terms of achievement, motivation, and expectation. It was found that the ideas the students had regarding language achievement impacted the relationship between goal achievement, motivation, and self-determination. The students who reported negative perceptions tended to have lower motivation levels; however, surprisingly, another group of students who reported themselves as being poor language learners were motivated to push themselves harder in order to achieve their goals. In another view, Mori (1999) found that students who claimed that they were highly capable tended to be more successful than students who saw themselves as being less capable. However, Mori added that students with lower ability levels can compensate for their limited abilities with positive beliefs and strive to achieve their language learning goals.

A number of studies have revealed the way in which self-perception influences such factors as the learning styles of students, as well as their expectations, choice of tasks, performance levels, and attitudes or beliefs regarding how the language should be both learned and taught. These judgments may help students to self-monitor their own capacity to learn a language. As a result, they can design their study plan more accurately, and they will know what to study, how much effort they will need to expend, and how long it will take them to overcome obstacles (Bandura \& Schunk, 1981; Hsieh \& Kang, 2010; Mori, 1999; Weiner, 1985).

\subsection{Beliefs about Language Learning}

Among scholars in the field of second language acquisition, the definition of beliefs about language learning has been provided to pinpoint the key function and impact on learning any language. Bernat and Gvozdenko (2005), defined beliefs, adopted from Fishbein and Ajzen (1975), Ajzen (1988) as "a central construct in every discipline that deals with human behavior and learning" (p. 1). Richardson (1996) described beliefs as "psychologically held understandings, premises, or propositions about the world that are felt to be true" (p. 103). In a classroom context, Pajares (1992) made a distinction between knowledge and beliefs by claiming that "belief is based on evaluation and judgment; knowledge is based on objective fact." Abdolahzadeh and Nia (2014), drawing from White (1999), noted that "language learners' expectations are developed prior to their experiences, and are also influenced and shaped by their beliefs." Moreover, the students' beliefs influenced their performances and experiences with language learning. The identifications of the beliefs of students also has the potential to better understand their approaches to language, as well as providing language teachers with ideas to find more effective methods of language instruction (Horwitz, 1999).

Previous studies have been conducted to confirm the role of self-belief in language learning, but the number of studies in this field climbed dramatically following Horwitz's pioneering study. Horwitz (1985) investigated the beliefs of trainee foreign language teachers regarding language learning via the 34-item Beliefs about Language Learning Inventory (BALLI) self-report questionnaire. However, in this study, Horwitz did not reveal the results of the questionnaire, because her intention was to indicate whether or not the BALLI questionnaire was useful for trainees, for example, the influence of their beliefs on their future performances as language teachers.

Nevertheless, following Horwitz's early study on this topic, theorists continue to conduct studies on the influence of self-belief on language learning, especially in terms of learning English as Foreign Language (EFL). Peacock (2001) conducted a study to investigate changes in the beliefs of trainee English as a Second Language (ESL) teachers regarding second language learning through a learner self-report questionnaire based on Horwitz's BALLI model. The participants believed that second language acquisition was based on their knowledge of grammar and vocabulary acquisition, and that those who could speak more than one language were considered to be very intelligent. This led to the conclusion that such beliefs could influence lesson plans, classroom activities, and the choice of learning materials. As a result of such a belief, a teacher could pay too much attention to vocabulary and grammar. Besides which, the belief that those who can speak more than one language are very intelligent may also result in a bias. They should also be aware of the potential bias of such beliefs when they evaluate their future students.

More recently, Mohibi and Khodadady (2011) investigated the beliefs of university students regarding language learning via BALLI's model. The study indicated that the students believed that learning English in a native English speaking country was preferential, and that anybody has the ability to learn to speak English. Therefore, language teachers should be aware of the beliefs of students regarding language learning, as well as their own, in order to allow their students to become more proficient language learners. In an another context, Ariogul, Unal, and Onursal (2009) investigated the differences and similarities between the beliefs of English, German, and 
French second language students with regard to language learning, via BALLI's questionnaire. It was found that French students tended to be more motivated, and had more confidence about learning and speaking a second language than any of the other groups. It was also found that the French students had higher levels of achievement in language learning than any of the other groups. Therefore, affirmative beliefs or positive thinking could be considered one of the keys to the successful acquisition of a foreign language.

In Thailand, there have been several previous studies concerning beliefs in language learning conducted by Thai educators. Vibulphol (2004) investigated the beliefs of Thai pre-service EFL teachers regarding language learning during their years of teaching practice. It was found that prior to this period, most of the participants reported the belief that everyone has the ability to learn English; that speaking skills are easier to learn than other skills, that anyone can achieve English fluency in five years, and that knowledge of English grammar, vocabulary, and culture are also key factors to success. Subsequently, after years of teaching practice, there were three aspects which had changed significantly. More of the participants had increased confidence regarding their English ability, and were more concerned with English pronunciation, while fewer participants felt that English was important for further study. More recently, Suwanarak (2012) looked at the role of self-perception in English language learning among Thai Master's degree students. The results indicated that many students evaluated themselves as failures in language learning, while a lower percentage rated themselves as having a higher level of English proficiency, and reported the frequent use of English language learning strategies. It was also discovered that the motivation levels of students can be related to their use of strategy. The consistent findings of Howchatturat and Jaturapitakkul (2011) revealed that Thai undergraduate students self-reported their belief that language difficulties, motivation, and instructional methods had the greatest impact on their success. The correlation between the motivational beliefs of students, and the difficulties with language that they experienced had an impact on their use of strategy. In another study, Fujiwara (2014) produced a research paper entitled: "Language Learning Beliefs of Thai EFL University Students: Dimensional Structure and Cultural Variation", which demonstrated that the past learning experience of an individual influences the development and formation of their use of strategies, as well as their cultural background.

\section{Methods}

\subsection{Research Questions}

According to the literature review and statement of the problem, the researchers made an effort to answer the following research questions: a) What did the low-proficiency students report as their beliefs regarding English language learning? b) What did the high-proficiency students report as their beliefs regarding English language learning? c) What were the most prevalent affirmative or positive beliefs about English language learning among both low and high proficiency students? and d) what were the differences and similarities between the beliefs of both low and high proficiency students regarding English language learning?

\subsection{Participants}

The total population of the study consisted of 4,140 students, and was composed of a low proficiency group (Group 1) and a high proficiency group (Group 2). In the former group, the students were enrolled in an intermediate-level English course, while the students in the latter group were in an upper-intermediate level English course. Through the use of the random sampling technique, the participants consisted of 495 students, with 252 in Group 1, and 243 in Group 2. The mean age of both groups were the same, at 19 years of age, and the mean amount of time spent learning the language was also the same, at 13 years. The rest of the data, which included aspects including field of study and gender, are shown in Table 1.

Table 1. Participant information

\begin{tabular}{lllll}
\hline & \multicolumn{2}{l}{ Group 1 (Low proficiency) } & \multicolumn{2}{l}{ Group 2 (High proficiency) } \\
\cline { 2 - 5 } & $\mathrm{N}$ & $(\%)$ & $\mathrm{N}$ & $(\%)$ \\
\hline Field of study & & & & \\
Social Sciences \& Humanities & 89 & 35.30 & 92 & 37.90 \\
Health Sciences & 77 & 30.60 & 118 & 48.60 \\
Science \& Technology & 86 & 34.10 & 33 & 13.60 \\
Gender & & & & \\
Female & 164 & 65.10 & 155 & 63.80 \\
Male & 88 & 34.90 & 88 & 36.20 \\
\hline
\end{tabular}




\subsection{Instrument}

The questionnaire used in this study was comprised of two parts: a) demographic information, which was also used to obtain information about age, gender, and the number of years spent studying English, and b) a modified, 33-item version of the 'Beliefs about Language Learning Inventory' or BALLI model provided by Horwitz (1987). The modified version of the BALLI questionnaire was used to measure a student's beliefs about learning English as a Foreign Language. The self-report questionnaire was in the five-point Likert Scale format, ranging from one (Strongly Disagree) to five (Strongly Agree). However, the questionnaire was limited to five factors related to the beliefs of the students: a) the difficulties of language learning, b) an aptitude for foreign languages, c) the nature of language learning, d) learning and communication strategies, and d) motivations and expectations.

The questionnaire was translated independently into Thai by two Thai English linguists. As the English proficiency levels of the participants were at various levels, the questionnaire was therefore translated into Thai to ensure that all of the participants completely understood all of the questions. Translation experts, statistics experts, and psychologists were also asked to check the appropriateness of the test content validity, based on the Item Objective Congruence (IOC) Index.

\subsection{Data Collection Procedures}

The data in this study were collected during the second semester of the 2013 academic year. Letters were sent to selected faculties to request permission to collect data from their students. Prior to data collection, the participants were asked if they were willing to participate in this study. After that, the modified version of Students' Beliefs about Learning English as a Foreign Language Questionnaire was administered to the willing participants.

\subsection{Data Analysis}

The data was analyzed with regard to the research questions. The descriptive statistics of means, standard deviations, and frequencies were used as data from the demographic information, and the modified version of the BALLI questionnaire.

\section{Results}

In this section, the quantitative data about the beliefs of Thai students regarding the English language are reported in accordance with the research questions, as follows:

\subsection{Beliefs about English Language Learning among Low-Proficiency Students}

Table 2. Beliefs about English language learning reported by low-proficiency students

\begin{tabular}{|c|c|c|c|c|c|}
\hline \multicolumn{2}{|r|}{ Beliefs about English language learning } & \multirow{2}{*}{$\frac{M}{3.52}$} & \multirow{2}{*}{$\begin{array}{l}\text { S.D. } \\
1.088\end{array}$} & \multirow{2}{*}{$\begin{array}{l}\begin{array}{l}\text { Level of } \\
\text { Agreement }\end{array} \\
\text { Agree }\end{array}$} & \multirow{2}{*}{$\frac{\text { Ranking }}{16}$} \\
\hline 1 & $\begin{array}{l}\text { I think that learning English most effectively is achieved by students } \\
\text { under the age of } 20 \text {. }\end{array}$ & & & & \\
\hline 2 & $\begin{array}{l}\text { I think that everybody has their own ability level in terms of learning } \\
\text { English. }\end{array}$ & 3.59 & .967 & Agree & 15 \\
\hline 3 & $\begin{array}{l}\text { I think that Thai people can learn English as well as other non-native } \\
\text { English speakers. }\end{array}$ & 2.80 & .925 & $\begin{array}{l}\text { Somewhat } \\
\text { agree }\end{array}$ & 29 \\
\hline 4 & $\begin{array}{l}\text { I think that to learn English well, we should know at least one other } \\
\text { foreign language. }\end{array}$ & 2.81 & 1.041 & $\begin{array}{l}\text { Somewhat } \\
\text { agree }\end{array}$ & 28 \\
\hline 5 & $\begin{array}{l}\text { I think that learners who are good at Mathematics and Sciences tend } \\
\text { to learn English well. }\end{array}$ & 2.63 & 1.025 & $\begin{array}{l}\text { Somewhat } \\
\text { agree }\end{array}$ & 30 \\
\hline 6 & I think that people who are multilingual are intelligent. & 3.83 & 1.101 & Agree & 11 \\
\hline 7 & $\begin{array}{l}\text { I think that anybody can speak English when they have the } \\
\text { opportunity to use it and the time to practice it. }\end{array}$ & 4.18 & .999 & Agree & $2 *$ \\
\hline 8 & $\begin{array}{l}\text { I think that English is easier to learn in comparison to other foreign } \\
\text { languages. }\end{array}$ & 3.52 & .948 & Agree & 16 \\
\hline 9 & $\begin{array}{l}\text { I think that I can understand English better in comparison to other } \\
\text { foreign languages. }\end{array}$ & 3.31 & .990 & $\begin{array}{l}\text { Somewhat } \\
\text { agree }\end{array}$ & 21 \\
\hline 10 & $\begin{array}{l}\text { I think that I can speak English better in comparison to other foreign } \\
\text { languages. }\end{array}$ & 3.23 & 1.004 & $\begin{array}{l}\text { Somewhat } \\
\text { agree }\end{array}$ & 23 \\
\hline
\end{tabular}


Table 2. Beliefs about English language learning reported by low-proficiency students (continued)

\begin{tabular}{|c|c|c|c|c|}
\hline Beliefs about English language learning & M & S.D. & $\begin{array}{l}\text { Level of } \\
\text { Agreement }\end{array}$ & Ranking \\
\hline $\begin{array}{l}\text { I think that I can read in English better in comparison to other } \\
\text { foreign languages. }\end{array}$ & 3.44 & .998 & Agree & 19 \\
\hline $\begin{array}{l}\text { I think that I can write English better compared to other foreign } \\
\text { languages. }\end{array}$ & 3.30 & .989 & Agree & 22 \\
\hline $\begin{array}{l}\text { I think that Thai people can learn English better compared to foreign } \\
\text { languages, as the structure of English and Thai are similar. }\end{array}$ & 2.94 & .902 & $\begin{array}{l}\text { Somewhat } \\
\text { agree }\end{array}$ & 26 \\
\hline $\begin{array}{l}14 \text { I think that an awareness of the culture of foreign countries will help } \\
\text { people learn foreign languages. }\end{array}$ & 3.49 & .830 & Agree & 17 \\
\hline $\begin{array}{l}15 \text { I think that studying in a country where English is spoken as a native } \\
\text { language will increase one's ability to learn English. }\end{array}$ & 3.99 & 1.095 & Agree & $4^{*}$ \\
\hline 16 I think that vocabulary is essential to learn English. & 4.21 & 1.060 & $\begin{array}{l}\text { Strongly } \\
\text { agree }\end{array}$ & $1^{*}$ \\
\hline 17 I think that grammar is essential to learn English. & 3.64 & .970 & Agree & 13 \\
\hline $\begin{array}{l}18 \text { I think that we should translate from English into Thai when we } \\
\text { learn English. }\end{array}$ & 2.84 & .912 & $\begin{array}{l}\text { Somewhat } \\
\text { agree }\end{array}$ & 27 \\
\hline $\begin{array}{l}19 \text { I think that practice is necessary for learning English to be used in } \\
\text { real communicative situations. }\end{array}$ & 4.18 & 1.099 & Agree & $2^{*}$ \\
\hline $\begin{array}{l}20 \text { I think that as a beginner, we should not be afraid of making some } \\
\text { grammatical mistakes when speaking. }\end{array}$ & 3.77 & .960 & Agree & 12 \\
\hline $\begin{array}{l}\text { I think that when I meet foreigners, I would like to practice speaking } \\
\text { English with them. }\end{array}$ & 3.41 & .977 & Agree & 20 \\
\hline $\begin{array}{l}22 \text { I think that when we read and listen to English, and find some } \\
\text { difficult vocabulary, we should guess its meaning from the context. }\end{array}$ & 3.63 & .963 & Agree & 14 \\
\hline 23 I think that regular practice will help people learn English better. & 4.18 & .988 & Agree & $2^{*}$ \\
\hline $\begin{array}{l}\text { 24. I think that I am not embarrassed when I speak English in front of } \\
\text { other people. }\end{array}$ & 3.22 & .913 & $\begin{array}{l}\text { Somewhat } \\
\text { agree }\end{array}$ & 24 \\
\hline $\begin{array}{l}25 \text { I think that when I pronounce English incorrectly, it will be difficult } \\
\text { to solve this problem. }\end{array}$ & 3.05 & .989 & $\begin{array}{l}\text { Somewhat } \\
\text { agree }\end{array}$ & 25 \\
\hline $\begin{array}{l}26 \text { I think that listening to native pronunciation from songs or movies } \\
\text { will improve my speaking and listening abilities. }\end{array}$ & 3.91 & 1.062 & Agree & $7^{*}$ \\
\hline $\begin{array}{l}27 \text { I think that I am not embarrassed when I speak English in front of } \\
\text { other people. }\end{array}$ & 3.45 & 1.042 & Agree & 18 \\
\hline $\begin{array}{l}28 \text { I think that I have to learn English because I have to communicate } \\
\text { with foreigners. }\end{array}$ & 3.85 & .962 & Agree & $9 *$ \\
\hline $\begin{array}{l}29 \text { I think that I want to have foreign friends to communicate in English } \\
\text { with. }\end{array}$ & 3.84 & 1.034 & Agree & $10^{*}$ \\
\hline $\begin{array}{l}30 \text { I think that I want to learn English because I need to access } \\
\text { information worldwide. }\end{array}$ & 3.88 & .983 & Agree & $8^{*}$ \\
\hline 31 I think that English is essential for postgraduate education. & 3.97 & 1.160 & Agree & $5^{*}$ \\
\hline 32 I think that high English abilities will help me to get a better job. & 4.13 & 1.078 & Agree & $3^{*}$ \\
\hline $\begin{array}{l}\text { I think that enhanced English language abilities will become more } \\
\text { recognized in our society. }\end{array}$ & 3.96 & 1.095 & Agree & $6^{*}$ \\
\hline Beliefs about English language learning & 3.57 & .509 & Agree & \\
\hline
\end{tabular}

According to Table 2, the low-proficiency students in this study agreed with the overall beliefs about English language learning $(M=3.57)$. With regard to individual items, the students strongly agreed that learning English vocabulary was essential for them $\left(1^{\text {st }}\right.$ ranking $\left.=4.21\right)$. They thought that anybody could speak English given the opportunity and time to practice, and that practice is necessary to learn the type of English used in real, communicative situations, and that regular practice will also help learners to acquire the language $\left(2^{\text {nd }}\right.$ ranking, $M=4.18$ ). In addition, having strong English abilities was believed to assist those students in getting a better job ( $3^{\text {rd }}$ ranking, $M=4.13$ ), studying in countries where English is spoken as a native language, such as the US, the UK, and Australia, will enhance the development of their English abilities $\left(4^{\text {th }}\right.$ ranking, $\left.M=3.99\right)$. For 
low-proficiency students, English is essential in order continue to postgraduate education ( $5^{\text {th }}$ ranking, $M=3.97$ ). 4.2 Beliefs about English Language Learning among High-Proficiency Students

Table 3. Beliefs about English language learning reported by high-proficiency students

\begin{tabular}{|c|c|c|c|c|}
\hline Beliefs about English language learning & M & S.D. & $\begin{array}{l}\text { Level of } \\
\text { Agreement }\end{array}$ & Ranking \\
\hline $\begin{array}{l}\text { I think that learning English most effectively is achieved by students } \\
\text { under the age of } 20 \text {. }\end{array}$ & 3.54 & 1.147 & Agree & 23 \\
\hline $\begin{array}{l}\text { I think that everybody has their own ability level in terms of learning } \\
\text { English. }\end{array}$ & 3.62 & .982 & Agree & 22 \\
\hline $\begin{array}{l}\text { I think that Thai people can learn English as well as other non-native } \\
\text { English speakers. }\end{array}$ & 2.76 & .910 & $\begin{array}{l}\text { Somewhat } \\
\text { agree }\end{array}$ & 27 \\
\hline $\begin{array}{l}\text { I think that to learn English well, we should know at least one other } \\
\text { foreign language. }\end{array}$ & 2.39 & 1.086 & Disagree & 30 \\
\hline $\begin{array}{l}5 \text { I think that learners who are good at Mathematics and Sciences tend to } \\
\text { learn English well. }\end{array}$ & 2.54 & 1.021 & Disagree & 29 \\
\hline 6 I think that people who are multilingual are intelligent. & 4.01 & .981 & Agree & $9 *$ \\
\hline $\begin{array}{l}7 \text { I think that anybody can speak English when they have the opportunity } \\
\text { to use it and the time to practice it. }\end{array}$ & 4.35 & .870 & $\begin{array}{l}\text { Strongly } \\
\text { agree }\end{array}$ & $2^{*}$ \\
\hline $\begin{array}{l}\text { I think that English is easier to learn in comparison to other foreign } \\
\text { languages. }\end{array}$ & 3.68 & 1.052 & Agree & 19 \\
\hline $\begin{array}{l}\text { I think that I can understand English better in comparison to other } \\
\text { foreign languages. }\end{array}$ & 3.85 & 1.037 & Agree & 15 \\
\hline $\begin{array}{l}10 \text { I think that I can speak English better in comparison to other foreign } \\
\text { languages. }\end{array}$ & 3.70 & 1.092 & Agree & 18 \\
\hline $\begin{array}{l}\text { I think that I can read in English better in comparison to other foreign } \\
\text { languages. }\end{array}$ & 3.90 & 1.052 & Agree & 12 \\
\hline $\begin{array}{l}12 \text { I think that I can write English better compared to other foreign } \\
\text { languages. }\end{array}$ & 3.77 & 1.022 & Agree & 16 \\
\hline $\begin{array}{l}\text { I think that Thai people can learn English better compared to foreign } \\
\text { languages, as the structure of English and Thai are similar. }\end{array}$ & 2.63 & .9500 & $\begin{array}{l}\text { Somewhat } \\
\text { agree }\end{array}$ & 28 \\
\hline $\begin{array}{l}14 \text { think that an awareness of the culture of foreign countries will help } \\
\text { people learn foreign languages. }\end{array}$ & 3.64 & .914 & Agree & 20 \\
\hline $\begin{array}{l}15 \text { I think that studying in a country where English is spoken as a native } \\
\text { language will increase one's ability to learn English. }\end{array}$ & 4.29 & .881 & $\begin{array}{l}\text { Strongly } \\
\text { agree }\end{array}$ & $4 *$ \\
\hline 16 I think that vocabulary is essential to learn English. & 4.29 & .849 & $\begin{array}{l}\text { Strongly } \\
\text { agree }\end{array}$ & $4^{*}$ \\
\hline 17 I think that grammar is essential to learn English. & 3.74 & .929 & Agree & 17 \\
\hline $\begin{array}{l}18 \text { I think that we should translate from English into Thai when we learn } \\
\text { English. }\end{array}$ & 3.00 & 1.027 & $\begin{array}{l}\text { Somewhat } \\
\text { agree }\end{array}$ & 26 \\
\hline $\begin{array}{l}19 \text { I think that practice is necessary for learning English to be used in real } \\
\text { communicative situations. }\end{array}$ & 4.46 & .896 & $\begin{array}{l}\text { Strongly } \\
\text { agree }\end{array}$ & $1^{*}$ \\
\hline $\begin{array}{l}20 \text { I think that as a beginner, we should not be afraid of making some } \\
\text { grammatical mistakes when speaking. }\end{array}$ & 3.86 & 1.007 & Agree & 14 \\
\hline $\begin{array}{l}21 \text { I think that when I meet foreigners, I like to practice speaking English } \\
\text { with them. }\end{array}$ & 3.42 & 1.067 & Agree & 24 \\
\hline $\begin{array}{l}\text { I think that when we read and listen to English, and find some difficult } \\
\text { vocabulary, we should guess its meaning from the context. }\end{array}$ & 3.88 & .995 & Agree & 13 \\
\hline 23 I think that regular practice will & 4.34 & .937 & $\begin{array}{l}\text { Strongly } \\
\text { agree }\end{array}$ & $3^{*}$ \\
\hline $\begin{array}{l}24 \text { I think that I am not embarrassed when I speak English in front of other } \\
\text { people. }\end{array}$ & 3.28 & 1.026 & $\begin{array}{l}\text { Somewhat } \\
\text { agree }\end{array}$ & 25 \\
\hline $\begin{array}{l}25 \text { I think that when I pronounce English incorrectly, it will be difficult to } \\
\text { solve this problem. }\end{array}$ & 3.00 & 1.054 & $\begin{array}{l}\text { Somewhat } \\
\text { agree }\end{array}$ & 26 \\
\hline
\end{tabular}


Table 3. Beliefs about English language learning reported by high-proficiency students (continued)

\begin{tabular}{|c|c|c|c|c|}
\hline Beliefs about English language learning & $\mathrm{M}$ & S.D. & $\begin{array}{l}\text { Level of } \\
\text { Agreement }\end{array}$ & Ranking \\
\hline $\begin{array}{l}\text { I think that listening to native pronunciation from songs or movies will } \\
\text { improve my speaking and listening abilities. }\end{array}$ & 4.26 & .891 & $\begin{array}{l}\text { Strongly } \\
\text { agree }\end{array}$ & $5 *$ \\
\hline $\begin{array}{l}27 \text { I think that I am not embarrassed when I speak English in front of other } \\
\text { people. }\end{array}$ & 3.63 & 1.147 & Agree & 21 \\
\hline $\begin{array}{l}28 \text { I think that I have to learn English because I have to communicate with } \\
\text { foreigners. }\end{array}$ & 3.98 & .989 & Agree & $10^{*}$ \\
\hline $\begin{array}{l}\text { I think that I want to have foreign friends to communicate in English } \\
\text { with. }\end{array}$ & 3.95 & 1.023 & Agree & 11 \\
\hline $\begin{array}{l}\text { I think that I want to learn English because I need to access information } \\
\text { worldwide. }\end{array}$ & 4.02 & .929 & Agree & $8^{*}$ \\
\hline 31 I think that English is essential for postgraduate education. & 4.25 & .973 & $\begin{array}{l}\text { Strongly } \\
\text { agree }\end{array}$ & $6^{*}$ \\
\hline 32 I think that high English & 4.29 & .923 & $\begin{array}{l}\text { Strongly } \\
\text { agree }\end{array}$ & $4^{*}$ \\
\hline $\begin{array}{l}\text { I think that enhanced English language abilities will become more } \\
\text { recognized in our society. }\end{array}$ & 4.07 & .938 & Agree & $7^{*}$ \\
\hline Beliefs about English language learning & 3.71 & .496 & Agree & \\
\hline
\end{tabular}

In the table above, the results of the high-proficiency group revealed that their overall beliefs about English language learning were mostly positive $(M=3.71)$. For separated items, they strongly believed that practice is necessary in order to learn English for use in real-life communicative situations $\left(1^{\text {st }}\right.$ ranking, $\left.M=4.46\right)$. In the second ranking, the opportunity to practice and use English correctly was highly regarded, as the students believed that this would enable anyone to speak the language $(M=4.35)$, and that if students regularly practiced the language, their abilities would develop more quickly $\left(3^{\text {rd }}\right.$ ranking, $\left.M=4.34\right)$. Besides, they also strongly agreed that studying in a native English speaking country would enhance their language abilities, that vocabulary acquisition was necessary for them to learn English, and that a high level of English abilities would help then get a better job $\left(4^{\text {th }}\right.$ ranking, $\left.M=4.29\right)$. They also strongly agreed that in order to improve their speaking and listening abilities, they had to listen to native pronunciation from songs or movies $(M=4.26)$.

\subsection{The Most Positive Beliefs about English Language Learning among the Two Groups}

Table 4. A comparison of the top-ten affirmative beliefs about English language learning reported by both groups

\begin{tabular}{|c|c|c|c|c|}
\hline \multirow{2}{*}{ Ranking } & \multicolumn{4}{|c|}{ Beliefs about English Language Learning } \\
\hline & Item & Low proficiency & Item & High proficiency \\
\hline 1 & 16. & $\begin{array}{l}\text { I think that vocabulary is essential to } \\
\text { learning English. }\end{array}$ & 19. & $\begin{array}{l}\text { I think that practice is necessary for learning } \\
\text { English to be used in real communicative } \\
\text { situations. }\end{array}$ \\
\hline \multirow[t]{3}{*}{2} & 7. & $\begin{array}{l}\text { I think that anybody can speak English } \\
\text { when they have the opportunity to use it } \\
\text { and the time to practice it. }\end{array}$ & 7. & $\begin{array}{l}\text { I think that anybody can speak English when } \\
\text { they have the opportunity to use it and the } \\
\text { time to practice it. }\end{array}$ \\
\hline & 19. & $\begin{array}{l}\text { I think that practice is necessary for } \\
\text { learning English to be used in real } \\
\text { communicative situations. }\end{array}$ & & \\
\hline & 23. & $\begin{array}{l}\text { I think that regular practice will help me to } \\
\text { learn English better. }\end{array}$ & & \\
\hline 3 & 32. & $\begin{array}{l}\text { I think that a high level of English abilities } \\
\text { will help me to get a better job. }\end{array}$ & 23. & $\begin{array}{l}\text { I think that regular practice will help me to } \\
\text { learn English better. }\end{array}$ \\
\hline 4 & 15. & $\begin{array}{l}\text { I think that studying in a country where } \\
\text { English is spoken as a native language will } \\
\text { increase one's ability to learn English. }\end{array}$ & 15. & $\begin{array}{l}\text { I think that studying in a country where } \\
\text { English is spoken as a native language will } \\
\text { increase one's ability to learn English. }\end{array}$ \\
\hline
\end{tabular}


Table 4. A comparison of the top-ten affirmative beliefs about English language learning reported by both groups (continued)

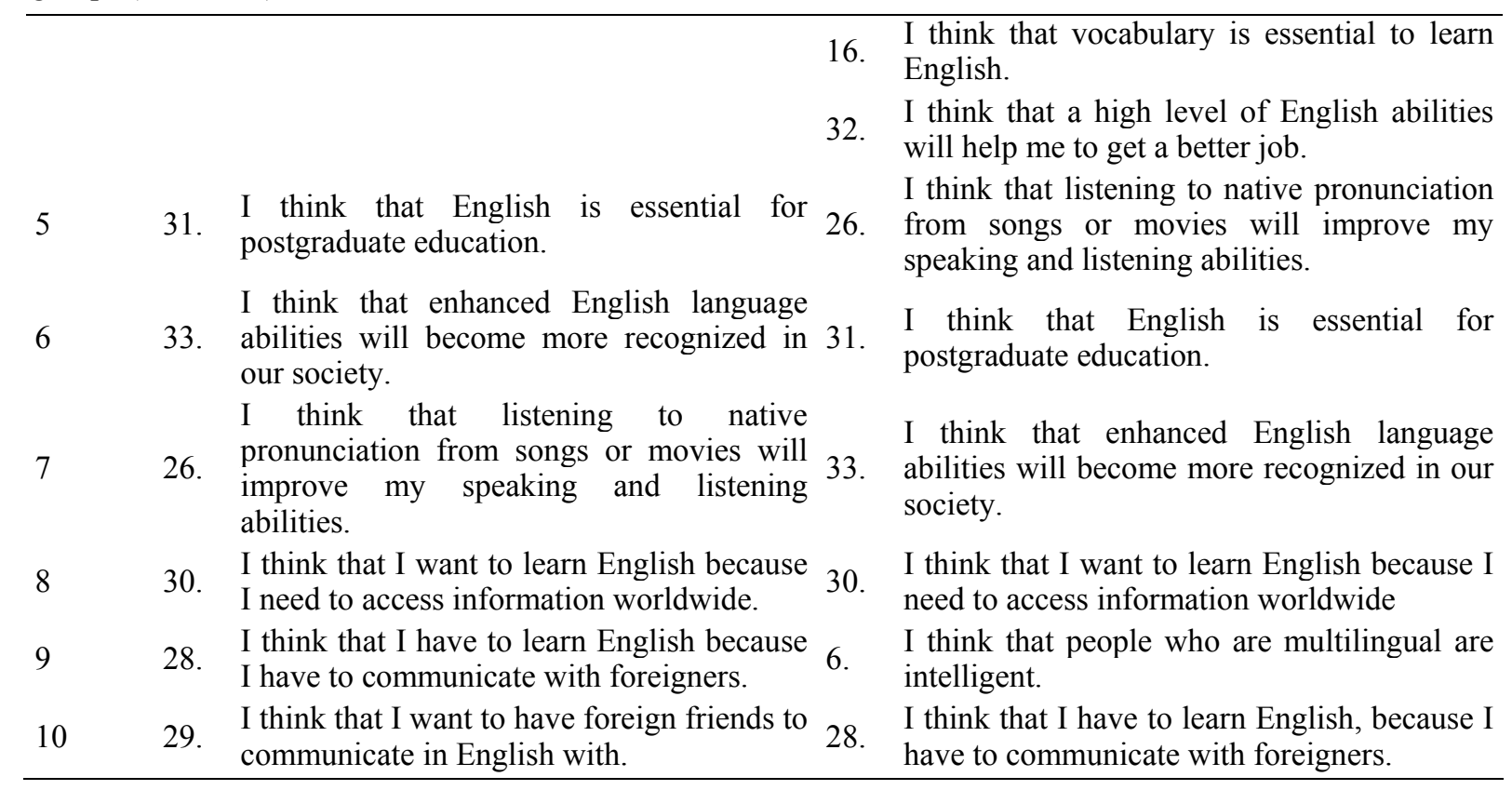

In Table 4, the top-ten affirmative beliefs about English language learning among the two groups were compared. It can be clearly seen that the beliefs of both groups in terms of items 7,15 , and 30 were ranked similarly, $2^{\text {nd }}, 4^{\text {th }}$, and $8^{\text {th }}$ respectively. Even though the other rankings were identified with different items, those items were actually the same (items 16, 19, 23, 26, 28, 31,32, and 33), with the exception of items 6 and 29.

4.4 Different Beliefs about English Language Learning among Low and High-Proficiency Students

Table 5. A comparison of the different beliefs about English language learning among these two groups

\begin{tabular}{|c|c|c|c|c|c|c|}
\hline \multirow{2}{*}{\multicolumn{2}{|c|}{ Beliefs about English language learning }} & \multicolumn{2}{|c|}{$\begin{array}{l}\text { Low proficiency } \\
\text { (LP) }\end{array}$} & \multicolumn{2}{|c|}{$\begin{array}{l}\text { High } \\
\text { proficiency (HP) }\end{array}$} & \multirow{2}{*}{ - Remarks } \\
\hline & & \multirow{2}{*}{$\frac{\mathrm{M}}{2.81}$} & \multirow{2}{*}{$\begin{array}{l}\text { Level of } \\
\text { Agreement }\end{array}$} & \multirow{2}{*}{$\begin{array}{l}\mathrm{M} \\
2.39\end{array}$} & \multirow{2}{*}{$\begin{array}{l}\begin{array}{l}\text { Level of } \\
\text { Agreement }\end{array} \\
\text { Disagree }\end{array}$} & \\
\hline 4 & $\begin{array}{l}\text { I think that to learn English well, we should know at least } \\
\text { one other foreign language. }\end{array}$ & & & & & $\mathrm{LP}>\mathrm{HP}$ \\
\hline 5 & $\begin{array}{l}\text { I think that learners who are good at Mathematics and } \\
\text { Sciences tend to learn English well. }\end{array}$ & 2.63 & $\begin{array}{l}\text { Somewhat } \\
\text { agree }\end{array}$ & 2.54 & Disagl & IP \\
\hline 7 & $\begin{array}{l}\text { I think that anybody can speak English when they have the } \\
\text { opportunity to use it and the time to practice it. }\end{array}$ & 4.18 & Agree & 4.35 & $\begin{array}{l}\text { Strongly } \\
\text { agree }\end{array}$ & $\mathrm{P}$ \\
\hline 9 & tand English better in comparison to & 3.31 & $\begin{array}{l}\text { Som } \\
\text { agre }\end{array}$ & 3.85 & Agree & $\mathrm{H}$ \\
\hline 10 & $\begin{array}{l}\text { I think that I can speak English better in comparison to } \\
\text { other foreign languages. }\end{array}$ & 3.23 & $\begin{array}{l}\text { Somewhat } \\
\text { agree }\end{array}$ & 3.70 & Agree & \\
\hline & $\begin{array}{l}\text { I think that studying in a country where English is spoken } \\
\text { as a native language will increase one's ability to learn } \\
\text { English. }\end{array}$ & 3.99 & Agree & 4.29 & $\begin{array}{l}\text { Strongly } \\
\text { agree }\end{array}$ & $\mathrm{P}$ \\
\hline 19 & $\begin{array}{l}\text { I think that practice is necessary for learning English to be } \\
\text { used in real communicative situations. }\end{array}$ & 4.18 & Agree & 4.46 & $\begin{array}{l}\text { Strongly } \\
\text { agree }\end{array}$ & $\mathrm{HP}>\mathrm{LP}$ \\
\hline 23 & $\begin{array}{l}\text { I think that regular practice will help me to learn English } \\
\text { better. }\end{array}$ & 4.18 & Agree & 4.34 & $\begin{array}{l}\text { Strongly } \\
\text { agree }\end{array}$ & HP \\
\hline & $\begin{array}{l}\text { I think that listening to native pronunciation from songs or } \\
\text { movies will improve my speaking and listening abilities. }\end{array}$ & 3.91 & Agree & 4.26 & $\begin{array}{l}\text { Strongly } \\
\text { agree }\end{array}$ & $\mathrm{HP}>\mathrm{LP}$ \\
\hline 31 & I think that English is essential for postgraduate education. & 3.97 & Agree & 4.25 & $\begin{array}{l}\text { Strongly } \\
\text { agree }\end{array}$ & $\mathrm{HP}$ \\
\hline
\end{tabular}


Regarding the results in Table 5, the different beliefs about English language learning among low and high-proficiency students were presented. Out of 33 items, there were 10 beliefs which the students ranked at different levels. The low-proficiency students agreed more with item 4 (i.e., they should know at least one foreign language to learn English well) and item 5 (i.e., learners who are good at Mathematics and Sciences tend to learn English well). On the other hand, the high-proficiency students strongly agreed with the following six beliefs, which included items 7, 15, 19, 23, 26, and 31 .

\section{Discussion}

The results of this study revealed an overview of the prevalent affirmative beliefs held by both low-and-high proficiency students. Most of the low-proficiency students reported that learning English vocabulary was essential. They also believed that if they were provided with the opportunity of regular English language practice, it would help them to do better in English. This can be explained by a salient feature of the Thai learning style. In Thailand, most students learn a foreign language by memorizing vocabulary and grammar rules in order to pass exams (Adam, 2011; Nguyen, 2005). As a result of this learning style, these students can be compared to the subjects of Peacock's (2001) study; the population of trainee ESL teachers who also reported that language learning is primarily about vocabulary and grammar acquisition and mastery, a similar result to the findings of Vibolphon's study (2004), which found that Thai pre-service EFL teachers reported that learning English grammar and vocabulary are the keys to success. The results of these studies are also in line with low-proficiency students. They believed that vocabulary knowledge would help them to master the English language, as well as pass English exams. In other words, one of the highest priority concerns among low-proficiency students was having a large enough vocabulary.

In contrast, the high-proficiency students, who claimed sufficient knowledge of the vocabulary and grammar rules, and therefore did not have to worry as much about passing tests, reported that they practiced English regularly, and that they took every opportunity to speak English in a real-life communicative situation. Similarly to the results of Biyeam (1997), Thai students have a desire to improve their communicative skills. However, one of the problems faced by Thai students is a lack of opportunity to practice these skills in their daily lives (Adam, 2011; Nguyen, 2005; Noom-ura, 2013).

It could be implied that the high-proficiency students are not in the process of obtaining vocabulary and grammar rules, but in the process of using the language in real-life situations. The findings were similar to those of Ariogul, Unal, and Onursal's (2009) study of high-proficiency students, who were more motivated and confident about speaking the language than the low-proficiency group. In this study, the high-proficiency students reported that they preferred regular English speaking practice, which implied that they were ready and willing to speak English.

Also, the results of the affirmative beliefs held by high-proficiency students were similar and related to the findings of theorists such as Howchatturat and Jaturapitakkul (2011), who found that the use of a variety of classroom management strategies were essential to helping students to master English. Langlois (as cited in Khunsamrong, 2010), claimed that Thai students cannot make practical use of the language they learned in the classroom to real-life situations. This may be due to the fact that their English teachers at school were too focused on vocabulary and grammar. Therefore, when they met foreigners, they were unable to communicate with them with confidence. Kayi (2006), asserted that the enhancement of communicative skills should be based on real-life situations, and that the speaking and practice activities provided to the students should prepare them for real-life communication with foreigners.

Regarding the comparison of the prevalent affirmative or positive beliefs of both groups, the findings indicated similar beliefs, such as that anyone can speak English when they have the opportunity and the time to practice, that studying in a country where English is spoken as a native language would increase their ability to learn English, as well as the fact that English is necessary to access information worldwide, for example, on the internet. As previously mentioned, Thai students face a lack of opportunities to speak English both in the classroom, as well as outside of it. The consensus seems to be that studying in an English-speaking country seems to provide students with the most exposure to an English-speaking environment. Furthermore, in order to access modern knowledge and to reach a broad spectrum of resources, it is essential to be able to read books, magazines, textbooks, articles, academic articles in the form of written materials and websites in the original English. Apparently, knowledge of English facilitates the students with keeping up to date with modern information resources, such as the internet (Biyeam, 1997; Khunsamrong, 2010; Pollap, 2010; Somdee \& Suppasetseree, 2013)

Nevertheless, there are some different beliefs about English language among the two groups. There are a higher 
percentage of low-proficiency students who believed that in order to learn English well, we should know at least one foreign language. On the other hand, a higher percentage of the high-proficiency students reported that they could understand English better compared to other foreign languages. The low-proficiency students also tended to believe that knowing or experiencing at least one foreign language could help them to learn English. Perhaps, this is because that these students have found their own methods or techniques for learning English. They also might have adopted their beliefs regarding learning strategies with their own foreign language learning experiences, which may help students to learn more easily and rapidly (Fujiwara, 2014; Howchatturat \& Jaturapitakkul, 2011; Suwanarak, 2012). Moreover, these learning strategies could also facilitate the comprehension of low-proficiency students and help them to learn faster (Oxford, 1990). On the other hand, high-proficiency students tended to believe that they could understand English better compared to other foreign languages.

\section{Conclusion}

The results of the study revealed that low-proficiency students believed that vocabulary was an essential aspect of English language learning, while high-proficiency students reported that regular practice was the key to their success. These students also reported the belief that anybody could speak English if they had the opportunity to practice speaking. The most affirmative or positive beliefs reported by both low-and-high-proficiency students, were as follows: a) anybody can speak English if given the opportunity and the time to practice, b) that this practice must include correct usage, and c) that they want access to information resources which use English, such as the internet. The major differences between the beliefs regarding English language learning among low and high proficiency students are as follows: a) In order to learn English well, one must know at least one other foreign language, and b) that they understand English better than other foreign language. For these reasons, a teacher of low-proficiency students should prepare vocabulary activities to enhance and build vocabulary and word skills. However, a teacher of high-proficiency students should create English speaking practice activities to give students the opportunity to practice speaking English in a real-life situation.

Even though the results of this study are limited to Thai EFL learners $(\mathrm{N}=495)$ in foundation English courses, certain pedagogical implications have arisen, as follows: first, in an effort to understand the factors that influence foreign language learning, this study analyzed the data from self-reported questionnaires in order to identify the beliefs of students regarding language learning. The self-reported information can be beneficial for teachers to plan appropriate classroom activities that are related to their students expectations, and to prepare more effective classroom activities, as well as creating a more effective learning environment. Second, the findings would be a valuable resource to assist redesigning English language courses, especially general English courses at the tertiary level, as well as learners with different levels of language proficiency. For further studies, experimental research, such as designing tailor-made language courses for low-and-high-proficiency students may be needed, and conducted in order to prove the quantitative data found herein. The triangulation techniques such as interviews and observations should be applied to the research in order to confirm the possible results.

\section{Acknowledgments}

The authors would like to take this opportunity to express their sincere appreciation to the International College for Sustainable Studies of Srinakharinwirot University for granting us the fund to conduct this research project.

\section{References}

Abdolahzadeh E., \& Nia, M. R. (2014). Language Learning Beliefs of Iranian Learners: Examining the Role of English Language Proficiency. Procedia-Social and Behavioral Sciences, 98, 22-28. http://dx.doi.10.1016/ j.sbspro.2014.03.384

Adam, P. (2011). Classroom Management Guidelines for EFL Teachers in the ASEAN Community. Proceeding of the ASEAN Scenario Analysis 2015-2020. Bangkok University Research Conference. Retrieved from http://proceedings.bu.ac.th/?download=59:classroom-management-guidelines-for-efl-teachers-in-the-aseancommunity\&start $=40$

Ariogul, S., Unal, D. C., \& Onursal, I. (2009). Foreign Language Learners' Beliefs about Language Learning: A Study on Turkish University Students. Procedia-Social and Behavioral Sciences, 1, 1500-1506. http://dx.doi:10.1016/j.sbspro.2009.01.265

Bandura, A. (1977). Self-efficacy: Toward a unifying theory of behavioral change. Psychological Review, 84(2), 191-215. http://dx.doi.10.1037/0033-295X.84 .2.191

Bandura, A., \& Schunk, D. H. (1981). Cultivating competence, self-efficacy, and intrinsic interest through proximal self-motivation. Journal of Personality and Social Psychology, 41, 586-598. 
http://dx.doi.10.1037/0022-3514.41.3.586

Bernat, E., \& Gvozdenko, I. (2005). Beliefs about language learning: Current knowledge, pedagogical implications and new research directions. TESL-EJ, 9(1). Retrieved from http://www-writing.berkeley.edu/ TESLEJ/ej33/a1.html

Biyaem, S. (1997). Learner Training: Changing Roles for a Changing World, Educational Innovation for Sustainable Development. 3rd UNESCO-ACEID International Conference, Bangkok.

Fujiwara, T. (2014). Language Learning Beliefs of Thai EFL University Students: Variations Related to Achievement Levels and Subject Majors. Electronic Journal of Foreign Language Teaching, 11(2), 300-311. Retrieved from http://e-flt.nus.edu.sg/main.htm

Horwitz, E. K. (1985). Using student beliefs about language learning and teaching on the foreign language methods course. Foreign Language Annals, 18(4), 333-340. http://dx.doi.10.1111/j.1944-9720.1985. tb01811.x

Horwitz, E. K. (1987). The beliefs about language learning. In A. Wenden, \& J. Rubin (Eds.), Learning strategies in language learning (pp. 119-129). Englewood Cliffs, NJ: Prentice Hall.

Horwitz, E. K. (1999). Cultural and situational influences on foreign language learners' beliefs about language learning: A review of BALLI studies. System, 27, 557-576. http://dx.doi.10.1016/S0346-251X(99)00050-0

Howchatturat, S., \& Jaturapitakkul, N. (2011). The relationship between Beliefs about English Language Learning and Perceptions of Metacognitive Strategies of Thai University Students. The Journal of Faculty of Applied Arts, 4(1), 1-11.

Hsieh, P., \& Kang, H. (2010). Attribution and self-efficacy and their interrelationship in the Korean EFL context. Language Learning, 60(3), 606-627. http://dx.doi.10.1111/j.1467-9922.2010.00570.x

Jernigan, C. G. (2011). What do students expect to learn? The role of learner expectancies, beliefs, and attributions for success and failure in student motivation. Current Issues in Education, 7(4). Retrieved from http://cie.asu.edu/ojs/index.php/cieatasu/article/view/824

Kayi, H. (2006). Teaching Speaking: Activities to Promote Speaking in a Second Language. The Internet TESL Journal, 12(11). Retrieved from http://iteslj.org/Articles/Kayi-Teaching Speaking.html

Khamkhien, A. (2010). Teaching English Speaking and English Speaking Tests in the Thai Context: A Reflection from Thai Perspective. English Language Teaching, 3(1), 184-190. http://dx.doi.10.5539/elt.v3n1p184

Khunsamrong, S. (2010). A study of the Problems Faced by Thai Students in Acquiring English with Specific Reference to the First Year Students at the Northern Campuses of Mahachulalongkornrajavidyalaya University. Buddhist Graduates' Dissertation. Retrieved from http://www.mcu.ac.th/En/articlecontent_desc. php?article_id=1130\&articlegroup_id $=246$

Kitao, K. (1996). Why do we teach English? The Internet TESL Journal, 2(4). Retrieved from http://iteslj.org/Articles/Kitao-WhyTeach.html

Mitchell, T. (2013). Why is English so poor in Thailand? Retrieved from http://www.ajarn.com/ajarn-guests/ articles/why-is-english-so-poor-in-thailand/

Mohibi, S. N., \& Khodadady, E. (2011). Shifts in beliefs about second language learning. RELC Journal, 40(1), 102-124. http://dx.doi.10.1177/0033688208101448

Mori, Y. (1999). Epistemological beliefs and language learning beliefs: What do language learners believe about their learning? Language Learning, 49(3), 377-415. http://dx.doi: 10.1111/0023-8333.00094

Nguyen, T. H. (2005). Thailand: Cultural Background for ESL/EFL Teachers. Retrieved from http://www.hmongstudies.org/ThaiCulture.pdf

Noom-ura, S. (2013). English-teaching problems in Thailand and Thai teachers' professional development needs. English Language Teaching, 6(11), 139-147. http://dx.doi.10.5539/elt.v6n11p139

Oxford, R. L. (1990). Language Learning Strategies: What teacher should know. Boston: Heinle \& Heinle.

Pajares, M. (1992). Teachers' beliefs and educational research: Cleaning up a messy construct. Review of Educational Research, 3, 307-332. http://dx.doi.10.3102/00346543062003307

Peacock, M. (2001). Pre-service ESL teachers' beliefs about second language learning: A longitudinal study. 
System, 29(2), 177-195. http://dx.doi.10.1016/S0346-251X(01)00010-0

Pollap, T. (2010). The Relationship between American cultural background knowledge and the English proficiency of Thai English major students. Srinakharinwirot University, Bangkok.

Richardson, V. (1996). The role of attitudes and beliefs in learning to teach. In J. Sikula (Ed.), Handbook of Research on Teacher Education. New York: Macmillan.

Saiyasombut, S., \& Voices, S. (2012). Thai Education Failures-Part 4: Dismal English-language training. Saksith Saiyasombut \& Siam Voices. Retrieved from http://asiancorrespondent.com/78647/thai-educationfailures-part-4-dismal-english-language-education/

Shuck, S. (1997). Using a research simulation to challenge prospective teachers' beliefs about mathematics. Teaching and Teacher Education, 13(5), 529-539. http://dx.doi.10.1016/S0742-051X(97)85541-2

Somdee, M., \& Suppasetseree, S. (2013). Developing English Speaking Skills of Thai Undergraduate Students by Digital Storytelling through Websites. Retrieved from http://litu.tu.ac.th/FLLT2013/www.fllt2013.org/ private_folder/Proceeding/166.pdf

Suwanarak, K. (2012). English language learning beliefs, learning strategies and achievement of Masters Students in Thailand. TESOL in Context. Retrieved from http://www.tesol.org.au/files/files/275_kasma_ suwanarak.pdf

Test and score data summary for TOEFL iBT ${ }^{\circledR}$ test. (2013). Retrieved from http://www.ets.org/s/toefl/pdf/ 94227_unlweb.pdf

Trinder, R. (2013). Business students' beliefs about language learning in a university context. English for Specific Purpose, 32, 1-11. http://dx.doi.10.1016/j.esp.2012.06.003

Vibulphol, J. (2004). Beliefs about language learning and teaching approaches of pre-service EFL teachers in Thailand (Unpublished Dissertation). Oklahoma State University.

Weiner, B. (1976). A theory of motivation for some classroom experiences. Journal of Educational Psychology, 71(1), 3-25. http://dx.doi.10.1037/0022-0663.71.1.3

Weiner, B. (1985). "Spontaneous" causal search. Psychological Bulletin, 97, 74-84. http:/dx.doi.10.1037/ 0033-2909.97.1.74

White, C. (1999). Expectations and emergent beliefs of self-instructed language learners. System, 27, 443-457. http://dx.doi.10.1016/S0346-251X(99)00044-5

Wiriyachitra, A. (2002). English language teaching and learning in Thailand in this decade. Retrieved from $\mathrm{http} / / /$ www.apecneted.org/resources/extlink.cfm?hitType=document\&result_format_id=4\&hitID $=402 \&$ hitS ubID $=0$ \&redir=English\%20Language $\% 20$ Teaching\%20and\%20Learning\%20in\%20Thailand.pdf

\section{Copyrights}

Copyright for this article is retained by the author(s), with first publication rights granted to the journal.

This is an open-access article distributed under the terms and conditions of the Creative Commons Attribution license (http://creativecommons.org/licenses/by/3.0/). 